\title{
Geoecological Monitoring of Karst Water in Georgia, Caucasus (Case Study of Racha Limestone Massif)
}

\author{
Lasha Asanidze ${ }^{1}$, Guranda Avkopashvili², Kukuri Tsikarishvili' ${ }^{1}$, Zaza Lezhava1, \\ Nino Chikhradze ${ }^{1,3}$, Marika Avkopashvili4, Zurab Samkharadze ${ }^{5}$, Giorgi Chartolani1
}

\footnotetext{
${ }^{1}$ Department of Geomorphology and Geoecology, Vakhushti Bagrationi Institute of Geography, Ivane Javakhishvili Tbilisi State University, Tbilisi, Georgia

${ }^{2}$ Condensed Matter Physics Department, Andronikashvili Institute of Physics, Ivane Javakhishvili Tbilisi State University, Tbilisi, Georgia

${ }^{3}$ School of Natural Sciences and Engineering, Ilia State University, Tbilisi, Georgia

${ }^{4}$ Department of Geography, Ivane Javakhishvili Tbilisi State University, Tbilisi, Georgia

${ }^{5}$ R. Agladze Institute of Chemistry and Electrochemistry, Ivane Javakhishvili Tbilisi State University, Tbilisi, Georgia

Email: ${ }^{*}$ lasha.asanidze@tsu.ge
}

How to cite this paper: Asanidze, L., Avkopashvili, G., Tsikarishvili, K., Lezhava, Z., Chikhradze, N., Avkopashvili, M., Samkharadze, Z. and Chartolani, G. (2017) Geoecological Monitoring of Karst Water in Georgia, Caucasus (Case Study of Racha Limestone Massif). Open Journal of Geology, 7, 822829.

https://doi.org/10.4236/ojg.2017.76056

Received: May 12, 2017

Accepted: June 12, 2017

Published: June 15, 2017

Copyright (c) 2017 by authors and Scientific Research Publishing Inc. This work is licensed under the Creative Commons Attribution International License (CC BY 4.0).

http://creativecommons.org/licenses/by/4.0/ c) (†) Open Access

\begin{abstract}
Karst groundwater is the major natural resource of drinking water for many countries in the world. Especially in karstic regions, karst water requirements for settlements are provided from karst aquifers. Also, we should consider, that karst groundwater is becoming more and more valuable for drinking water supply. Thus, karst groundwater quality and permanent ecological monitoring are very important for populations. Moreover, if we consider that the karst landscape is the extremely sensitive system towards anthropogenic activities, since exaclty the anthropogenic activities largely identify the karst water pollution-turbidity causing factors. This paper presents a new study regarding the quality of the karst groundwater of the study area, which contains important resource of drinking water. In the mentioned study, 12 water samples were collected from different locations of the 4 main karst springs (Krikhula, Dolabistavi, Kidobana and Sakishore) during the spring and summer of 2014 and 2015 years. The main aim was to identify chemical compositions ( $\mathrm{Ni}, \mathrm{Ag}, \mathrm{Co}, \mathrm{Cd}, \mathrm{Zn}, \mathrm{Pb}, \mathrm{Al}, \mathrm{Mg}, \mathrm{Fe}, \mathrm{F}, \mathrm{Cu}$ ), and also, it was important to detect Escherichia coli (E. coli). Our research regarding all these chemical compositions shows that all the values are low and under the environmental limit according to the Georgian standards. We measured chemical parameters of all these samples by Atomic Absorption Spectroscopy (AAS) in the chemical laboratory of Ivane Javakhishvili Tbilisi State University, country of Georgia.
\end{abstract}




\section{Keywords}

Karst Water, Geoecological Monitoring, Limestone Massif, Georgia

\section{Introduction}

Nowadays, for many countries, a major resource of drinking water is karst groundwater. In the world, millions of people are provided by drinking water from karst aquifers, which contain valuable freshwater resources, and also, karst groundwater plays a crucial role for economic development of various countries and regions [1] [2]. At the same time, we should consider that karst aquifers are particularly vulnerable to contamination resulting from human activities [3] [4] [5] [6] [7].

Today, groundwater contamination is the most concern problem in karstic regions around the world. Karst groundwater is a potentially faster contaminated freshwater resources, due to increasing population density, rapid urbanization, as well as domestic and industrial usage [8]-[13]. Thus, karst groundwater quality and permanent ecological monitoring are very important, because the hydrochemical investigation provides significant information about water quality and characteristics of karst system [14] [15] [16] [17].

In this paper, we present a new study of karst groundwater including geochemical compositions in the Racha limestone massif, where karst groundwater is one of the most important sources of drinking water, which represents considerable natural resource for the study area.

The novelty of this work lies in the fact that such a survey was conducted for the first time in the karst springs. For the first time, the content of heavy metals in karst waters was identified by laboratory studies. Based on the methods used, it is possible to conduct similar surveys on other limestone massifs of Georgia.

Also, in the future, if we foresee the predicted increase in fresh drinking water demand, a comprehensive study of karst groundwater is very important both for the chosen area and the whole country as well. Quality of drinking water is one of the big problems in this country. In the different regions of Georgia, local population has water supply problems, which are caused by various factors (agriculture, urbanization and other).

Therefore, the results of this study present important information on karst groundwater quality of the study area. Based on our research, we can say that the quality of karst groundwater is completely good and safe for human health.

\section{Study Area and Geological Settings}

In Georgia, karst is represented only western part of the country, and occupies $6.4 \%$ of the entire territory of Georgia, that is about $4475 \mathrm{~km}^{2}$ [18] [19]. Karst line along the southern slope of the Caucasus mountain range extends $325 \mathrm{~km}$ in length from the Psou River to the Ertso Lake area.

The Racha limestone massif is the biggest karst massif in Georgia (the total area of which exceeds $590 \mathrm{~km}^{2}$ ), which is located in the eastern part of the karst 
zone of western Georgia (Figure 1). Geographically, the limestone massif is lo cated in the Oni and Ambrolauri municipalities. The study area belongs to the medium and high mountainous regions in Georgia. The highest elevation of the Racha limestone massif is $2402 \mathrm{~m}$ above sea level [20] [21]. Also, at high hypsometric altitudes are located Dolabistavi (1170 m a.s.l), Kidobana (1177 m a.s.l), and Sakishore (1165 m a.s.l) karst springs, which are significant fresh water reserves. Krikhula karst spring is located at a relatively low hypsometric altitude (701 $\mathrm{m}$ a.s.1).

The Racha limestone massif is a classic karst region throughout the Caucasus in terms of karst processes development. The Bajocian porphyritic suite is the basis of the massif and Cretaceous carbonate rocks also influence the structure of the stratigraphy [22]. Rocks from almost every part of the Early and Late Cretaceous exist in the region.

The massif consists mainly of upper and lower Cretaceous and Paleogene limestones, which have an important influence on the origin and development of the surface and underground karst features and on the water table and its fluctuations due to their geologic characteristic [23].

The prominence of karst processes in the region is considerably high, due to the rapid movement of water along the structural weaknesses in the limestones. The fault dislocations provide groundwater infiltration; there is a rapid infiltration and inflow of surface water and almost no surface flow on the surface of the massif. Some small surface streams are mostly associated with the rainy and snowmelt periods.

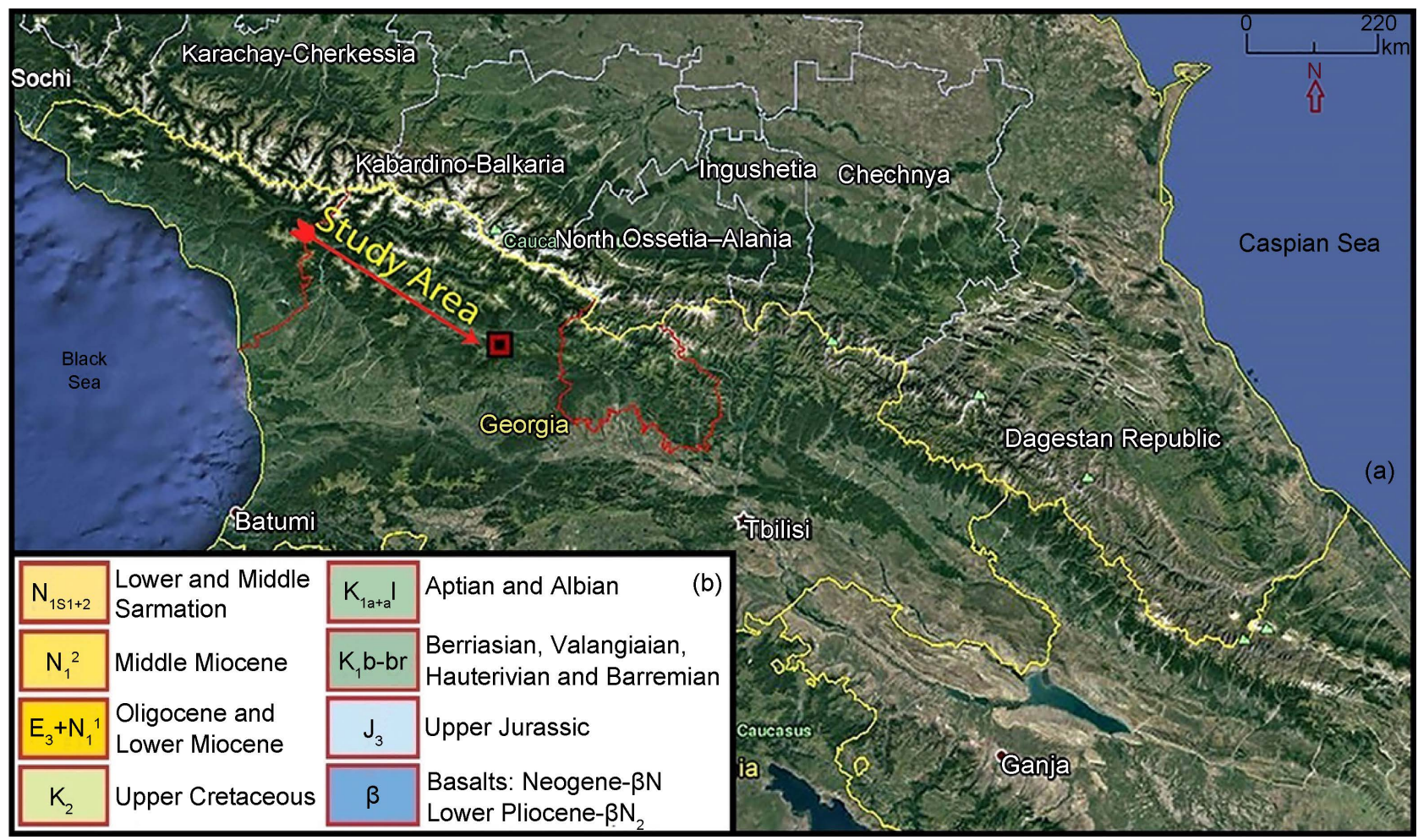

Figure 1. (a) Location of the Racha limestone massif (west Georgia). (b) Geological settings of the study area [24]. 


\section{Research Methods}

\section{Water sampling}

Water samples were collected in $1000 \mathrm{ml}$ (HDPE) plastic bottles. The plastic bottles were washed and rinsed 3 times with distilled water. Preservation of water samples was done by adding 2 drops of concentrated $\mathrm{HNO}_{3}$ (trace metal grade) to each sample. Each bottle was labeled according to the sampling location and time. The samples were then put into the insulated box and taken to the laboratory for further processing.

Water samples were filtered with Whatman $0.45 \mu \mathrm{m}$ filter paper in a Buchner funnel and heated at $100^{\circ} \mathrm{C}$ until the volume was reduced to $50 \mathrm{ml}$ in the normal volumetric flask of $50 \mathrm{ml}$. The volume was made up with acidified water (made up with acidified water: $3 \mathrm{~mL}$ concentrated $\mathrm{HNO}_{3}+1 \mathrm{~L}$ distilled water). Samples were analyzed by Atomic Absorption Spectroscopy (which identifies data by minimum errors) in the chemical laboratory of the Ivane Javakhishvili Tbilisi State University, country of Georgia.

\section{Results and Discussion}

We studied the following parameters in the water samples: the water chemical indicator $(\mathrm{pH})$; oxygen chemical requirement in the organic substances and ammonium ions. In addition, the microbiological indicator-Escherichia coli ( $E$. coli) was identified in the water samples that was not observed in any of the water samples (Table 1).

Content of heavy metals were identified in the same samples, including nickel $(\mathrm{Ni})$, silver $(\mathrm{Ag})$, cobalt $(\mathrm{Co})$, lead $(\mathrm{Pb})$, zinc $(\mathrm{Zn})$, aluminum $(\mathrm{Al})$, fluorine $(\mathrm{F})$, manganese $(\mathrm{Mg})$, iron $(\mathrm{Fe})$, cadmium $(\mathrm{Cd})$, and copper $(\mathrm{Cu})$.

The study revealed that the heavy metal content in the karst waters does not exceed the Environmental limits, which makes possible to use the karst springs as drinking water. The research results are important, as in the study area, the population faces the seasonal water problems. Figures 2-5 show the data obtained through the chemical analysis.

According to the laboratory studies of the karst water samples, collected in summer of 2014, it was identified that out of the present water samples only in the Krikhula karst water was detected the excessive amount of the lead $(\mathrm{Pb})$ ions, which was $0.07 \mathrm{mg} / \mathrm{l}$; in this case, environmental limit is $0.03 \mathrm{mg} / \mathrm{l}$ according to Georgian standards (Figure 6).

Table 1. Content of some of the chemical characteristics in the karst waters.

\begin{tabular}{cccccc}
\hline $\begin{array}{c}\text { Name of } \\
\text { parameteres }\end{array}$ & $\begin{array}{c}\text { Environmental } \\
\text { limit }\end{array}$ & $\begin{array}{c}\text { Krikhula } \\
\text { Karst Spring }\end{array}$ & $\begin{array}{c}\text { Dolabistavi } \\
\text { Karst Spring }\end{array}$ & $\begin{array}{c}\text { Kidobana } \\
\text { Karst Spring }\end{array}$ & $\begin{array}{c}\text { Sakishore } \\
\text { Karst Spring }\end{array}$ \\
\hline $\mathrm{pH}$ & $6.5-8.5 \mathrm{pH}$ & 7.3 & 7.1 & 7.2 & 7.2 \\
$\begin{array}{c}\text { Oxygen Chemical } \\
\text { requirement }\end{array}$ & $15-30 \mathrm{mg} / \mathrm{l}$ & 18 & 17 & 21 & 20 \\
$\begin{array}{c}\text { Ammonium ions } \\
\text { E-coli }\end{array}$ & $0.38 \mathrm{mg} / 1$ & 0.11 & 0.10 & 0.15 & 0.14 \\
\hline
\end{tabular}




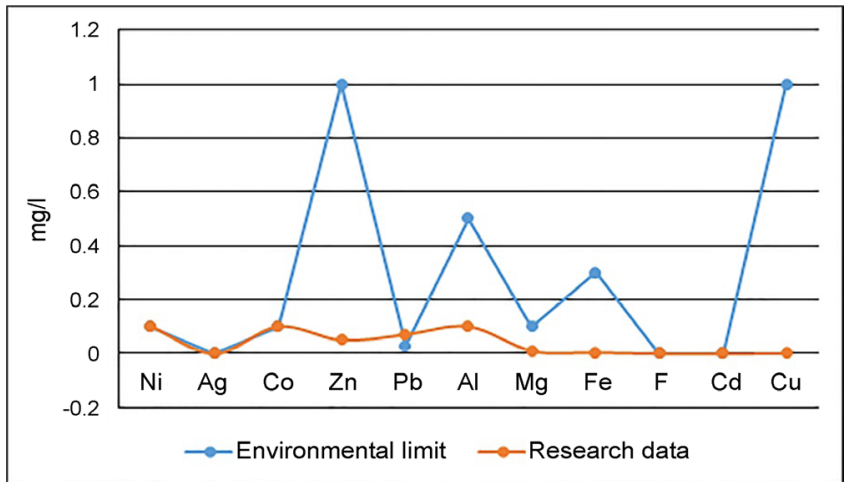

Figure 2. Heavy metals concentration in the Krikhula karst spring.

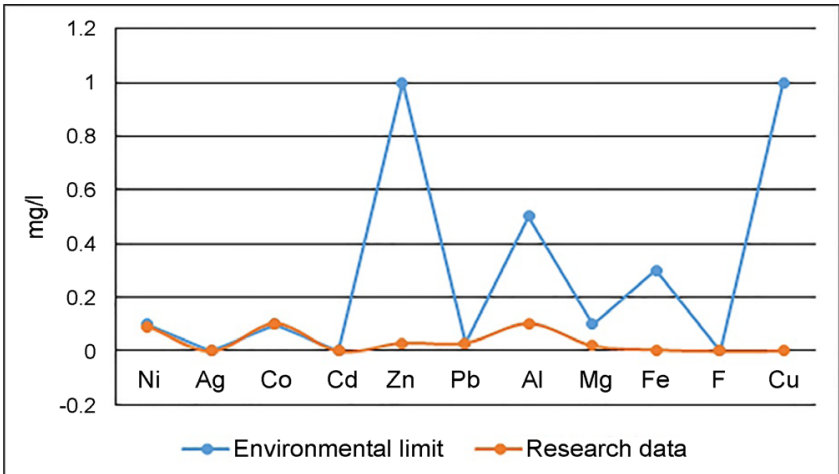

Figure 3. Heavy metals concentration in the Dolabistavi karst spring.

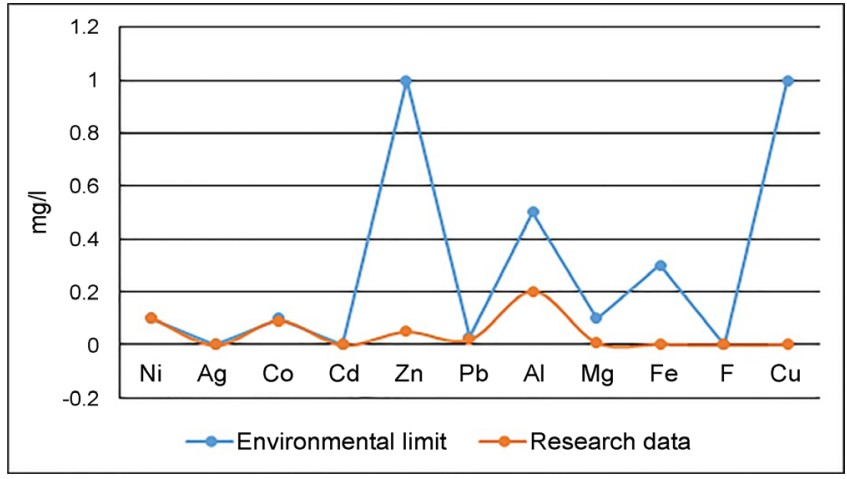

Figure 4. Heavy metals concentration in the Kidobana karst spring.

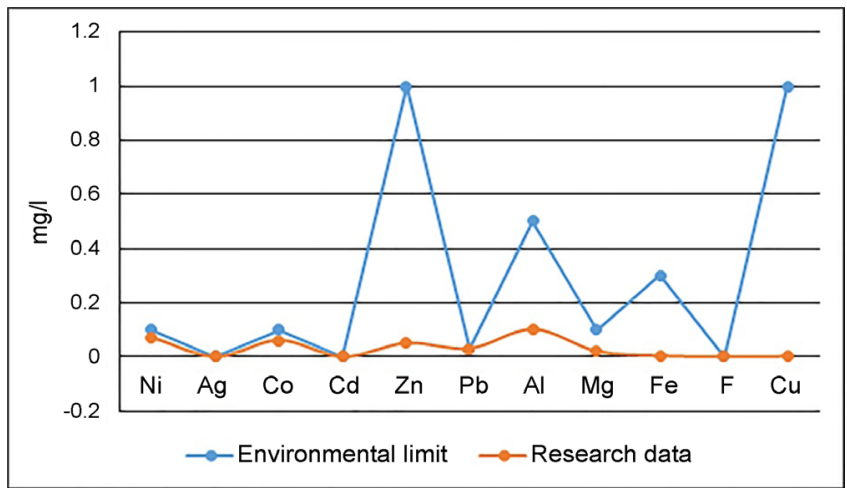

Figure 5. Heavy metals concentration in the Sakishore karst spring. 


\begin{tabular}{|c|c|c|c|c|c|c|c|}
\hline $\begin{array}{l}\text { Names of } \\
\text { parameters }\end{array}$ & $\begin{array}{l}\text { Environmental } \\
\text { limit (mg/l) }\end{array}$ & $\begin{array}{l}\text { Research } \\
\text { data }(\mathrm{mg} / \mathrm{l})\end{array}$ & & & $\begin{array}{c}\text { Names of } \\
\text { parameters }\end{array}$ & $\begin{array}{l}\text { Environmental } \\
\text { limit }(\mathrm{mg} / \mathrm{l})\end{array}$ & $\begin{array}{l}\text { Research } \\
\text { data }(\mathrm{mg} / \mathrm{l})\end{array}$ \\
\hline Nickel (Ni) & 0.1 & 0.1 & & & Nickel (Ni) & 0.1 & 0.09 \\
\hline Silver (Ag) & 0.0005 & 0.0001 & & & Silver (Ag) & 0.0005 & 0.0001 \\
\hline Cobalt (Co) & 0.1 & 0.1 & & & Cobalt (Co) & 0.1 & 0.1 \\
\hline Zinc $(Z n)$ & 1.0 & 0.05 & & & Zinc $(Z n)$ & 1.0 & 0.03 \\
\hline Lead $(\mathrm{Pb})$ & 0.03 & $\underline{0.07}$ & & & Lead $(\mathrm{Pb})$ & 0.03 & 0.03 \\
\hline Aluminum (Al) & 0.5 & 0.1 & & & Aluminum (Al) & 0.5 & 0.1 \\
\hline Manganeze (Mg) & 0.1 & 0.01 & & & Manganeze (Mg) & 0.1 & 0.02 \\
\hline Iron (Fe) & 0.3 & 0.005 & & & Iron (Fe) & 0.3 & 0.005 \\
\hline Flourine $(F)$ & 0.001 & 0.0001 & & & Flourine (F) & 0.001 & 0.0001 \\
\hline Cadmium (Cd) & 0.001 & 0 & & & Cadmium (Cd) & 0.001 & 0.0002 \\
\hline Copper (Cu) & 1.0 & 0.001 & (a) & (b) & Copper (Cu) & 1.0 & 0.002 \\
\hline $\begin{array}{l}\text { Names of } \\
\text { parameters }\end{array}$ & $\begin{array}{l}\text { Environmental } \\
\text { limit (mg/l) }\end{array}$ & $\begin{array}{l}\text { Research } \\
\text { data }(\mathrm{mg} / \mathrm{l})\end{array}$ & (c) & (d)] & $\begin{array}{c}\text { Names of } \\
\text { parameters }\end{array}$ & $\begin{array}{l}\text { Environmental } \\
\text { limit }(\mathrm{mg} / \mathrm{l})\end{array}$ & $\begin{array}{l}\text { Research } \\
\text { data }(\mathrm{mg} / \mathrm{l})\end{array}$ \\
\hline Nickel (Ni) & 0.1 & 0.1 & & & Nickel (Ni) & 0.1 & 0.07 \\
\hline Silver (Ag) & 0.0005 & 0.0001 & & & Silver (Ag) & 0.0005 & 0.0002 \\
\hline Cobalt (Co) & 0.1 & 0.09 & & & Cobalt (Co) & 0.1 & 0.06 \\
\hline Zinc (Zn) & 1.0 & 0.05 & & & Zinc (Zn) & 1.0 & 0.05 \\
\hline Lead $(\mathrm{Pb})$ & 0.03 & 0.02 & & & Lead $(\mathrm{Pb})$ & 0.03 & 0.03 \\
\hline Aluminum (Al) & 0.5 & 0.2 & & & Aluminum (Al) & 0.5 & 0.1 \\
\hline Manganeze $(\mathrm{Mg})$ & 0.1 & 0.01 & & & Manganeze (Mg) & 0.1 & 0.02 \\
\hline Iron $(\mathrm{Fe})$ & 0.3 & 0.004 & & & Iron $(\mathrm{Fe})$ & 0.3 & 0.004 \\
\hline Flourine $(F)$ & 0.001 & 0.0001 & & & Flourine (F) & 0.001 & 0.0002 \\
\hline Cadmium (Cd) & 0.001 & 0.0005 & & & Cadmium (Cd) & 0.001 & 0.0001 \\
\hline Copper (Cu) & 1.0 & 0.003 & & & Copper (Cu) & 1.0 & 0.002 \\
\hline
\end{tabular}

Figure 6. Heavy metals numerical data found in the water samples. (a). Krikhula karst spring, (b). Dolabistavi karst spring, (c). Kidobana karst spring, (d). Sakishore karst spring.

\section{Conclusions}

Important surveys were conducted in the years of 2014-2015 in the Racha limestone massif, where the drinking water supplies are important, in order to study the karst waters' chemical and microbiological characteristics. However, nowadays, unfortunately, by the Georgian legislation, the special characteristics of drinking water within karst regions are not very seriously taken into consideration in determining the criteria for karst water sources protection.

The results of our study provide important information for groundwater quality on the Racha limestone massif. By laboratory studies, conducted by us in the Dolabistavi, Kidobana and Sakishore karst springs, we found that in the study area, the chemical characteristics of the presented water samples meet the national standards, which means that the water samples do not include excessive 
amounts of various pollutants traces. Also, laboratory studies have found that none of the water samples showed any bacteriological indicators (E. coli). Thus, karst groundwater quality of the Racha limestone massif is good and quite safe for drinking purposes.

Based on this, we can state that the karst waters are completely safe for human health and in the future, it may facilitate the development of a strategic plan, which implies the karst waters to be used as drinking water for the Racha limestone massif.

Our intention was to conduct surveys in different smaller karst springs and carry out their laboratory testing, but due to financial shortages, we could not implement such surveys.

\section{Acknowledgements}

We would like to thank the Shota Rustaveli National Science Foundation for the research funding within the Doctoral Programs Grant No. DO/80/9-280/14. We also would like to thank the Vakhushti Bagrationi Institute of Geography for the financial support in the presented research.

\section{References}

[1] Nguyet, T.M., Thanh, V.P., Hai, V.D., Roi, N.D. and Tra, D.T. (2016) Hydrogeochemical Characterization and Groundwater Quality of the Dong Giao Karst Aquifer in Tam Diep, Ninh Binh, Vietnam. Acta Carsologica, 45, 233-242. https://doi.org/10.3986/ac.v45i3.3588

[2] Polomcic, D., Hajdin, B., Cuk, M., Papic, P. and Stevanovic, Z. (2014) Groundwater Resources for Drinking Water Supply in Serbia's Southeast Pannonian Basin. Carpathian Journal of Earth and Environmental Sciences, 9, 97-108.

[3] Guo, F., Yuan, D. and Qin, Z. (2010) Groundwater Contamination in Karst Areas of Southwestern China and Recommended Countermeasures. Acta Carsologica, 39, 389-399. https://doi.org/10.3986/ac.v39i2.107

[4] Ravbar, N. and Kovacic, G. (2006) Karst Water Management in Slovenia in the Frame of Vulnerability Mapping. Acta Carsologica, 35, 73-82. https://doi.org/10.3986/ac.v35i2-3.230

[5] Zwahlen, F. (Ed.) (2004) Vulnerability and Risk Mapping for the Protection of Carbonate (Karst) Aquifer-Final Report Cost Action 620, EUR 20912. European Commission, Directorate-Geneal for Research, Luxemburg, 297.

[6] Ford, D.C. and Williams, P. (2007) Karst Hydrogeology and Geomorphology. John Wiley, Chichester, 562. https://doi.org/10.1002/9781118684986

[7] Goldscheider, N. (2012) A Holistic Approach to Groundwater Protection and Ecosystem Services in Karst Terrains. Aqua Mundi-Am, 06046, 117-124.

[8] Adomako, D., Gibrila, A., Akiti, T., Fianko, R. and Maloszewski, P. (2011) Hydrogeochemical Evolution and Groundwater Flow in the Densu River Basin, Ghana. Journal of Water Resource and Protection, 3, 548-561.

https://doi.org/10.4236/jwarp.2011.37065

[9] Long, D.T., Voice, T.C., Niagolova, N.D. and McElmurry, S.P. (2012) Effects of Human Activities on Karst Groundwater Geochemistry in a Rural Area in the Balkans. Applied Geochemistry, 27, 1920-1931. 
[10] Chesnaux, R. (2012) Uncontrolled Drilling: Exposing a Global Threat to Groundwater Sustainability. Journal of Water Resource and Protection, 4, 746-749. https://doi.org/10.4236/jwarp.2012.49084

[11] Anderson, F. (2014) Multivariate Geostatistical Model for Groundwater Constituents in Texas. International Journal of Geosciences, 5, 1609-1617. https://doi.org/10.4236/ijg.2014.513132

[12] Madhlom, Q.A., Ansari, N.A. and Husain, M.H. (2016) Assessment of Groundwater Vulnerability in Northern Babylon Governorate, Iraq. Engineering. 8, 883-902. https://doi.org/10.4236/eng.2016.812080

[13] Avkopashvili, G., Avkopashvili, M., Gongadze, A. and Gakhokidze, R. (2017) EcoMonitoring of Georgia's Contaminated Soil and Water with Heavy Metals. Carpathian Journal of Earth and Environmental Sciences, 12, 595-604.

[14] Hunkeler, D. and Mudry, J. (2007) Hydrochemical Methods. In: Goldscheider, N. and David, D., Eds., Methods in Karst Hydrogeology, Taylor \& Francis, 93-121.

[15] Martonos, I.D. and Sabo, H.M. (2017) Quality of Drinking Water Supplies in Almasu Rural Area (Salaj County, Romania). Carpathian Journal of Earth and Environmental Sciences, 12, 371-376.

[16] Mudarra, M. and Andreo, B. (2010) Hydrogeological Functioning of Karst Aquifer Decuced from Hydrochemical Components and Natural Organic Tracers Present in Springs Waters. The Case of Yedra Spring (Southern Spain). Acta Carsologica, 39, 261-270. https://doi.org/10.3986/ac.v39i2.98

[17] Barberá, J.A. and Andreo, B. (2012) Functioning of a Karst Aquifer from Spain under Highly Variable Climate Conditions, Deduced from Hydrochemical Records. Environmental Earth Sciences, 65, 2337-2349. https://doi.org/10.1007/s12665-011-1382-4

[18] Asanidze, L., Tsikarishvili, K. and Bolashvili, N. (2013) Cave Tourism Potential in Georgia. The 2nd International Symposium on Kaz Mountains (Mount Ida) and Edremit, Edremit, 3-5 May 2013, Proceedings \& Abstracts, 243-247.

[19] Asanidze, L., Tsikarishvili, K. and Bolashvili, N. (2013) Speleology of Georgia. 16th International Congress of Speleology, Brno, 29-32.

[20] Kipiani, Sh. (1974) Karst of Georgia (Attempt of Geomorphological Characterization). V-I, Publishing House Metsniereba, Georgian, Tbilis, 13-20.

[21] Asanidze, L., Chikhradze, N., Lezhava, Z., Tsikarishvili, K., Polk, S.J., Lominadze, G. and Bolashvili, N. (2017) Complex Speleogenetic Processes and Mineral Deposition in the Caucasus Region of Georgia. Journal of Environmental Biology, In Print.

[22] Rakviashvili, K. (1985) On Karst of the Elevated Dzirula Massif and Shaori Tektonical Block. Caves of Georgia. The Collection, Issue 10, Tbilisi, 55-62. (In Russian)

[23] Asanidze, L., Chikhradze, N., Lezhava, Z., Tsikarishvili, K., Polk, J. and Chartolani, G. (2017) Sedimentological Study of Caves in the Zemo Imereti Plateau, Georgia, Caucasus Region. Open Journal of Geology. Scientific Research, 7, 465-477.

[24] Gudjabidze, G.E. (2003) Geological Map of Georgia, Scale 1:500,000. Georgian State Department of Geology and National Oil Company Saqnavtobi, Tbilisi. 
Submit or recommend next manuscript to SCIRP and we will provide best service for you:

Accepting pre-submission inquiries through Email, Facebook, LinkedIn, Twitter, etc. A wide selection of journals (inclusive of 9 subjects, more than 200 journals)

Providing 24-hour high-quality service

User-friendly online submission system

Fair and swift peer-review system

Efficient typesetting and proofreading procedure

Display of the result of downloads and visits, as well as the number of cited articles Maximum dissemination of your research work

Submit your manuscript at: http://papersubmission.scirp.org/

Or contact ojg@scirp.org 